ab. Je mehr eine Nervennaht unter Spannung steht, desto schlechter wird das Ergebnis. Die endoneurale Narbenbildung läßt sich am besten verhindern durch mikrochirurgische Adaptation einzelner Faszikel oder Faszikelgruppen des verletzten Nerven. Die Nahtspannung läßt sich vermeiden, wenn schon bei Nervendefekten, die noch weit unter der bisher gültigen kritischen Resektionslänge liegen, die therbrückung durch freie Transplantation körpereigener Hautnerven erfolgt. Die Ergebnisse der Wiederherstellung von bislang 21 peripheren Nerven durch autoplastische Kabeltransplantation unter Verwendung des Operationsmikroskopes werden mitgeteilt.

\title{
219. Der autologe Venenbypass als Operation der Wahl bei chronischen arteriellen Gefäßverschlüssen
}

\section{Komplikationen und Ergebnisse bei ca. 500 operierten Fällen}

\author{
R. de Pena Perez*, G. Rücker, R. Härng, St. John, B. Stallikamp, \\ L. C. Tung und J. WaLdschmidT-Berlin
}

\section{Autologous Venous By-Pass as the Operation of Choice in Chronic Arterial Occlusion \\ Results and Complications Seen in 500 Operations}

Summary. Since 1964, the autologous reversed vein graft operation for bridging peripheral arterial occlusions has been preferred at the Surgical Clinic of the Free University, Berlin. Aided by histological and angiographic control examinations as well as examinations with electro-magnetic instruments for circulatory measurements, we were able to demonstrate the satisfactory lodgement of the arterialized venous transplant and its positive functional adaptation.

Our own experience is based on 573 venous by-pass operations, of which 523 were in the legs. Thrombosis occurred in $16.3 \%$. The number of immediate (intraoperative) thromboses was $8.1 \%$ at the most. Other complications, such as late haemorrhages, secondary healing, anastomotic aneurysms and wound necrosis were much more rare.

In view of the good late results the autologous venous by-pass is recommended as an effective surgical treatment of peripheral arterial occlusion.

Zusammenfassung. Seit 1964 wird in der Chirurgischen Klinik der Freien Universität Berlin die autologe Venenumkehrplastik zur Utberbrückung peripherer arterieller Gefäßverschlüsse bevorzugt. An Hand von histologischen und angiografischen Verlaufsbeobachtungen sowie Untersuchungen mit elektromagnetischen Blutströmungsmeßgeräten konnte die gute Einheilung der arterialisierten Venentransplantate und deren positive Anpassungsvorgänge nachgewiesen werden.

Die eigenen Erfahrungen stützen sich auf 573 Venenbypässen, von denen 523 im Bereich der unteren Extremitäten angelegt worden sind. Fine Thrombosierung trat in 16,3\% ein. Dabei war die Anzahl der Sofortthrombosen mit 8,1\% am höohsten. Die anderen Komplikationen - wie Nachblutungen, Sekundärheilungen, Anastomosenaneurysmen und Wundrandnekrosen - waren sehr viel seltener. Auf Grund der guten Spätergebnisse wird der autologe Venenbypass als ein leistungsfähiges Operationsverfahren für die Behandlung peripherer arterieller GefäBverschlüsse empfohlen. 